Original Article

\title{
IN VITRO ANTIOXIDANT, ANTIMICROBIAL AND ADMET STUDY OF NOVEL FURAN/BENZOFURAN C-2 COUPLED QUINOLINE HYBRIDS
}

\author{
ANANTACHARYA RAJPUROHIT ${ }^{1}$, NAYAK D. SATYANARAYAN ${ }^{* 1}$, SAMEER PATIL ${ }^{2}$, KITTAPPA M. MAHADEVAN ${ }^{3}$, \\ ADARSHA H. J. ${ }^{4}$
}

1Department of Pharmaceutical Chemistry, Kuvempu University, Post Graduate Centre,Kadur577548, Chikkmagluru Dt., Karnataka St. India, ${ }^{2}$ Department of Post Graduate Studies and Research in Biochemistry, JnanaSahyadri, Kuvempu University,Shankaraghatta577451, Shivamogga Dt., Karnataka State, India, ${ }^{3}$ Department of Chemistry, Kuvempu University, Post Graduate Centre,Kadur577548, Chikkmagluru Dt., Karnataka St. India, ${ }^{4}$ Department of Inorganic and Physical Chemistry, Indian Institute of Science, Bangalore 560012 India Email: satya1782005@gmail.com

Received: 17 Jul 2017 Revised and Accepted: 21 Sep 2017

\section{ABSTRACT}

Objective: Synthesis of novel 2-(benzofuran-2-yl) and 2-(furan-2-yl) quinoline-4-carboxylates and their [2-(1-benzofuran-2-yl) quinolin-4-yl] methanol, [2-(1-furan-2-yl) quinolin-4-yl] methanol and its derivatives for antioxidant, antimicrobial and in silico pharmacokinetic study.

Methods: Synthesis was carried with the conventional method and the structures were confirmed by IR, ${ }^{1} \mathrm{H}$ NMR, ${ }^{13} \mathrm{C}$ NMR and mass spectral analysis. The antioxidant activity was performed by DPPH and $\mathrm{H}_{2} \mathrm{O}_{2}$ radical scavenging method. The antimicrobial investigation was established by cup plate and food poison technique. The in silico absorption, distribution, metabolism, excretion and toxicity (ADMET) study of the drug was carried out in ACD/lab-2.

Results: The antioxidant activity results revealed that compounds $4 b-c, 5 a-b, 10 c$ and 10 f exhibited good DPPH radical and hydrogen peroxide scavenging activity. The antibacterial results revealed that compounds 4c, 5a-b, 10b, 10d and 10f exhibited good activity against Escherichia coli, Klebsiella pneumonia and Salmonella typhimurium. Further, the antifungal activity results showed that compounds $4 \mathrm{c}$, 5c and $10 \mathrm{c}$-e were showing good activity against Aspergillusflavus and Candida neoformans. The mean value of $\mathrm{P}<0.05$ were considered to be statistically significant. The ADMET results revealed that compounds emerged as a potential candidate for antioxidant and antimicrobial agents.

Conclusion: The study reveals that compounds containing furan/benzofuran coupled heterocycles played the important role for activity as they possess potent antioxidant and antimicrobial agents. The in silico ADME analysis also suggesting the compounds were in acceptable range to obey the pharmacokinetic parameters.

Keywords: DPPH, Lipinski, ADMET, Toxicity, Escherichia coli and Aspergillusflavus

(C) 2017 The Authors. Published by Innovare Academic Sciences Pvt Ltd. This is an open access article under the CC BY license (http://creativecommons.org/licenses/by/4.0/) DOI: http://dx.doi.org/10.22159/ijpps.2017v9i11.21413

\section{INTRODUCTION}

Free radicals are species capable of free existence that contains one or more unpaired electrons which react with another molecule by accepting or donating the electrons [1]. The harmful intervention of reactive oxygen species (ROS) in normal metabolic processes leads to pathologic changes which is a consequence of their interaction with biomolecules inside and outside the cells [2, 3]. ROS contain molecules like hydrogen peroxide $\left(\mathrm{H}_{2} \mathrm{O}_{2}\right)$; hydroxyl radical $(\cdot \mathrm{OH})$ and superoxide (Oz-), by the generation of ROS, there is an alteration in the normal functioning of the cell and leads to pathophysiological changes. Free radicals are responsible for causing a wide number of health hazards such as cancer, ageing, heart diseases and gastric problems, etc. Oxygen free radicals disintegrate DNA and destroy cell membranes by enzymatic metabolic processes [4-6]. In nature's collection of biologically active molecules, benzofuran derivatives constitute a major group [7-9]. Benzofuran ring systems bearing substitutions at the C-2 position are widely distributed in nature and have been reported to have antioxidant, antiviral, antifungal activities [10, 11], antimicrobial [12, 13], anti-inflammatory [14], antipsychotic [15], analgesic [16], antilipidemic [17] and CNS stimulant activities [18]. Investigation of benzofuran derivatives in search of new drugs or to increase the efficacy of the present drugs has been most frequent approach [19]. Similarly, furan and its analogues were found to be biologically useful. 2-(furan-2-yl) quinoline-4-carboxylic acid and its analogues were reported to have the inhibiting property of $C$. albicans prolyl-tRNA synthetase and showed potent in vitro antifungal activities against dermatophytes [20, 21], 2-(furan-2-yl)-4-(phenoxy) quinoline derivatives were screened for cytotoxicity and anti-inflammatory activities [22], 4- (phenylamino) furo-[2, 3-b] quinoline and 2-(furan-2-yl)-4(phenylamino) quinoline derivatives for cytotoxicity evaluation and 1-\{4-[(furo[2, 3-b] quinoline-4-yl) amino] phenyl $\}$ ethanone exhibited potent and broad spectrum of cytotoxicity [23, 24]. The quinoline ring system is an essential structural fragment of a large number of natural and synthesized compounds displaying interesting biological activities such as antimalarial, antibacterial, anti-asthmatic, antihypertensive, and anti-inflammatory [25-27]. Quinolines and their derivatives have been found applications as pharmaceuticals and agrochemicals, as well as being general synthetic building blocks [28-31]. Molecular hybridization is a rational approach to design new prototypes after coupling different pharmacophoric subunits that can be recognized by two or more biologic receptors [32]. These strategies have been used in drug discovery to increase the efficacy.

In view of these observations and in continuation of our work on drug discovery through cinchophene and their derivatives [33-36], herein we report a facile, inexpensive procedure in the preparation of novel hybrid molecules [2-(1-benzofuran-2-yl) quinolin-4-yl] methanol and [2-(1-furan-2-yl) quinolin-4-yl] methanol derivatives using mild conditions, and explored for their in vitro antioxidant, antimicrobial and preliminary in silico ADMET properties.

\section{MATERIALSANDMETHODS}

Materials

Chemicals used in the synthesis of compounds were from Alfa Aesar, Pvt. Ltd. Bangalore, India and Spectrochem Pvt. Ltd. Bangalore, India. The solvents were of reagent grade and when necessary, they 
were purified and dried. Melting points of the synthesized compounds were determined with the help of Raga digital melting point apparatus and are uncorrected; Infrared data were recorded on a Bruker spectrophotometer using $\mathrm{KBr}$ pellets. ${ }^{1} \mathrm{H}$ and ${ }^{13} \mathrm{C}$ NMR spectra were recorded on Bruker AVANCE II 400 and $100 \mathrm{MHz}$ instruments using DMSO-d6/CDCl 3 as a solvent and TMS as an internal standard; chemical shifts are expressed as $\delta$ values (ppm). The J values are expressed in Hertz (Hz). Mass spectra (MS) were recordedin JEOL GCMATE II LC-Mass spectrometer with electron impact ionization (EI) technique. Analytical thin-layer chromatography (TLC) was performed with precoated TLC sheets of silica gel 60 F254 (Merck, Darmstadt, Germany), visualized by long and short wavelength UV lamps (nm). Chromatographic purifications were performed on Merck silica gel (100-200 mesh).

\section{Methods}

\section{Synthesis of 1-(1-benzofuran-2-yl) ethanone(1)}

Synthesis of 1-(1-benzofuran-2-yl) ethanonewas achieved by the addition of salicylaldehyde (5.8 g, $0.047 \mathrm{~mol})$, chloroacetone $(4.3 \mathrm{~g}$, $0.047 \mathrm{~mol})$ to an alcoholic $\mathrm{KOH}(33 \%, 20 \mathrm{ml})$ solution and kept for stirring vigorously for about 2-3 h. maintaining a temperature 0-5 ${ }^{\circ} \mathrm{C}$. The resultant mixture was poured onto crushed ice. The separated solid was filtered and recrystallized from petroleum ether (60-80). The yield was $85 \%$, M. Pt.75-78 ${ }^{\circ} \mathrm{C}$.

General procedure for the synthesis of substituted 2-(1benzofuran-2-yl) quinoline-4-carboxylic acid 3(a-c)

A mixture of 1-(1-benzofuran-2-yl) ethanone (1.8 g, $0.0113 \mathrm{~mol})$ and substituted $1 \mathrm{H}$-indole-2, 3-dione $(1.5 \mathrm{~g}, 0.0113 \mathrm{~mol})$ in ethanol (10 $\mathrm{ml}$ ) and anaqueous solution of $\mathrm{KOH} \mathrm{(33 \% )} 5 \mathrm{ml}$ was added, the reaction mixture was stirred at $65-70{ }^{\circ} \mathrm{C}$ for about12-14 $\mathrm{h}$. The reaction mixture was extracted with ethyl acetate (2-3 times) and the aqueous layer was poured onto crushed ice, acidified with $10 \mathrm{M}$ $\mathrm{HCl}$ and the resulting mass was filtered and dried to get yellow amorphous powder, yield $80 \%$.

General procedure for the synthesis of substituted methyl 2-(1benzofuran-2-yl) quinoline-4-carboxylates 4 (a-c)

Analogues of 2-(1-benzofuran-2-yl) quinoline-4-carboxylic acids were dissolved in sufficient quantity of methanol with a catalytic amount of Conc. $\mathrm{H}_{2} \mathrm{SO}_{4}$ and the mixture were refluxed for about 10-12 h. The reaction mixture was cooled to room temperature and poured onto the crushed ice, filtered, washed with water, dried and recrystallized from petroleum ether $(60-80)$ and ethyl acetate $(3: 1 \mathrm{v} / \mathrm{v})$.

General procedure for the synthesis of substituted [2-(1benzofuran-2-yl) quinolin-4-yl] methanol 5(a-c)

To a $100 \mathrm{ml}$ round bottom flask, dissolve methyl 2-(1-benzofuran-2yl) quinoline-4-carboxylate in sufficient quantity of ethanol and maintain the reaction mixture below $5{ }^{\circ} \mathrm{C}$, followed by the addition of sodium borotetrahydride until effervesces ceases. Stir the reaction mixture overnight at room temperature and pour onto the crushed ice after neutralizing with $10 \mathrm{M} \mathrm{HCl}$. The solid mass obtained was filtered, washed with water, dried and recrystallized from ethyl alcohol.

\section{General procedure for the synthesis of substituted 2-(1-furan-2-} yl) quinoline-4-carboxylic acid 8(a-f)

The compounds 8 (a-f) was synthesized by literature method [37] with slight modification. After completion of the reaction, the reaction mixture was chilled in a nice bath. The solid mass of the sodium salt of cinchonic acid was collected by filtration. The residue was dissolved in water and acidified with $10 \%$ glacial acetic acid, filter the residue and repeatedly washed with ethyl acetate (4-5 times).

General procedure for the synthesis of substituted methyl2-(1furan-2-yl) quinolone-4-carboxylates 9(a-c)

Analogues of 2-(1-furan-2-yl) quinoline-4-carboxylic acids were dissolved in sufficient quantities of methanol with a catalytic amount of Conc. $\mathrm{H}_{2} \mathrm{SO}_{4}$ and was refluxed for about 12-14 h. The progress of the reaction was tartan by TLC. After completion, the reaction mixture was cooled to room temperature and poured onto the crushed ice. The resulting solid mass was filtered, washed with water, dried and recrystallized from petroleum ether (60-80).

General procedure for the synthesis of substituted [2-(1-furan2-yl) quinolin-4-yl] methanol 10 (a-f)

The synthesis of substituted [2-(1-furan-2-yl) quinolin-4-yl] methanol $10(a-f)$ is similarly to the synthesis of analogues $5(a-c)$.

\section{Spectral details}

\section{[2-(1-benzofuran-2-yl) quinolin-4-yl] methanol (5a)}

Yield: 78 \%. M. Pt. $154-156^{\circ} \mathrm{C}$; IR (KBr) $v_{\max } 3114$ (-O-H stretching), $3062,1665,1595,1253 \mathrm{~cm}^{-1} ;{ }^{1} \mathrm{H}$ NMR (DMSO- $d_{6}, 400 \mathrm{MHz}, \delta \mathrm{ppm}$ ): $8.20(1 \mathrm{H}, \mathrm{d}, J=8 \mathrm{~Hz}, \mathrm{H}-13), 8.10$ (1H, s, H-19), 7.87 (1H, d, J=12 Hz, H16), $7.58(4 \mathrm{H}, \mathrm{m}, \mathrm{H}-9,8,7,15), 7.50(1 \mathrm{H}, \mathrm{t}, J=8 \mathrm{~Hz}, \mathrm{H}-6), 7.353(1 \mathrm{H}, \mathrm{t}$, $J=1.2 \mathrm{~Hz}, \mathrm{H}-14), 7.260$ (1H, t, J=2.4 Hz, H-3), 5.25 (2H, s, H-20), 1.72 (1H, s, quinolin-4-yl] methanol-OH proton); ${ }^{13} \mathrm{C}$ NMR (DMSO-d ${ }_{6}, 100$ MHz, $\delta$ ppm): 159.1 (C, C-18), 157.1 (C, C-2), 156.6 (C, C-10), 154.5 (C, C-5), 154.0 (CH, C-13), 145.8 (CH, C-14), 141.2 (C, C-12), 139.6 (C, C-15), 123.6 (CH, C-16), 123.2 (CH, C-8), 122.6 (CH, C-9), $122.1(\mathrm{CH}$, C-7), 121.5 (C, C-4), 115.8 (C, C-17), 114.9 (CH, C-19), 113.9 (CH, C6), 108.5 (CH, C-3), $67.0\left(\mathrm{CH}_{2}, \mathrm{C}-20\right)$. Calcd. $275.3 \mathrm{gm} / \mathrm{ml}$. EI-MS $(\mathrm{m} / \mathrm{z}): 276.0(\mathrm{M}+1)$.

\section{[2-(1-benzofuran-2-yl)-6-chloroquinolin-4-yl] methanol (5b)}

Yield: $81 \%$. M. Pt. $206-208{ }^{\circ} \mathrm{C}$; IR (KBr), $v_{\max } 3120$ (-O-H stretching), $2920,1605,1260 \mathrm{~cm}^{-1} ;{ }^{1} \mathrm{H}$ NMR (DMSO- $\left.d_{6}, 400 \mathrm{MHz}, \delta \mathrm{ppm}\right): 8.16$ $(1 \mathrm{H}, \mathrm{d}, J=4 \mathrm{~Hz}, \mathrm{H}-13), 8.14$ (1H, s, H-19), 7.91(1H, d, $J=4 \mathrm{~Hz}, \mathrm{H}-8)$, $7.68(1 \mathrm{H}, \mathrm{t}, J=4 \mathrm{~Hz}, \mathrm{H}-8), 7.66(1 \mathrm{H}, \mathrm{d}, J=4 \mathrm{~Hz}, \mathrm{H}-14), 7.653(1 \mathrm{H}, \mathrm{d}$, $J=0.4 \mathrm{~Hz}, \mathrm{H}-7), 7.63(1 \mathrm{H}, \mathrm{s}, \mathrm{H}-3), 7.37(1 \mathrm{H}, \mathrm{t}, J=4 \mathrm{~Hz}, \mathrm{H}-9), 7.314(1 \mathrm{H}$, d, J=0.8 Hz, H-6), 5.23 (2H, s, H-21), 1.55 (1H, s, quinolin-4-yl] methanol-OH proton); ${ }^{13} \mathrm{C}$ NMR (DMSO- $\left.d_{6}, 100 \mathrm{MHz}, \delta \mathrm{ppm}\right): 154.9$ (C, C-18), 154.5 (C, C-5), 148.7 (C, C-2), 148.4 (C, C-10), 145.8 (C, C12), 131.4 (C, C-15), 131.2 (CH, C-14), 130.4 (CH, C-13), $128.6(\mathrm{CH}, \mathrm{C}-$ 7), 125.9 (C, C-4), 125.7 (C, C-17), 123.5 (CH, C-16), 122.7 (CH, C-8), 122.1 (CH, C-19), 115.5 (CH, C-9), 111.5 (CH, C-6), 106.6 (CH, C-3), $59.7\left(\mathrm{CH}_{2}, \mathrm{C}-21\right)$. Calcd. 309.30gm/ml. EI-MS (m/z): $276.0(\mathrm{M}+1)$.

\section{[2-(1-benzofuran-2-yl)-8-fluoroquinolin-4-yl] methanol (5c)}

Yield: 79 \%. M. Pt. $158-160{ }^{\circ} \mathrm{C}$; IR (KBr) $\nu_{\max } 3114$ (-O-H stretching), $3063,1597,1253 \mathrm{~cm}^{-1}$; ${ }^{1} \mathrm{H}$ NMR (DMSO- $d_{6}, 400 \mathrm{MHz}, \delta \mathrm{ppm}$ ): 8.20 (1H, d, J=8 Hz, H-16), 8.12 (1H, s, H-19), 7.89 (1H, d, J=8 Hz, H-6), $7.62(3 \mathrm{H}, \mathrm{m}, \mathrm{H}-15,9,7), 7.51(1 \mathrm{H}, \mathrm{t}, J=8 \mathrm{~Hz}, \mathrm{H}-8), 7.35(1 \mathrm{H}, \mathrm{t}, J=8 \mathrm{~Hz}$, $\mathrm{H}-14), 7.26(1 \mathrm{H}, \mathrm{t}, J=8 \mathrm{~Hz}, \mathrm{H}-3), 5.26(2 \mathrm{H}, \mathrm{s}, \mathrm{H}-21), 1.65(1 \mathrm{H}, \mathrm{s}$, quinolin-4-yl] methanol-OH proton); ${ }^{13} \mathrm{C}$ NMR (DMSO-d6,100 MHz, $\delta$ ppm):154.9 (C, C-18), 154.8 (C, C-5), 149.1 (C, C-2), 148.0 (C, C-10), 147.2 (C, C-12), 129.9 (CH, C-15), 129.4 (CH, C-14), 128.3 (C, C-13), 126.6 (CH, C-7), 125.7 (C, C-4), 124.8 (C, C-17), 123.4 (CH, C-16), $122.0(\mathrm{CH}, \mathrm{C}-8), 114.4(\mathrm{CH}, \mathrm{C}-9), 111.5(\mathrm{CH}, \mathrm{C}-6), 106.1(\mathrm{CH}, \mathrm{C}-3)$, $59.6\left(\mathrm{CH}_{2}, \mathrm{C}-21\right)$. Calcd. $293.00 \mathrm{gm} / \mathrm{ml}$.

\section{[6-chloro-2-(furan-2-yl) quinolin-4-yl] methanol (10a)}

Yield: 88 \%. M. Pt. $148-150{ }^{\circ} \mathrm{C}$; IR (KBr) $v_{\max } 3200$ (-O-H stretching), 2918, 1672, 1604, 1249, $748 \mathrm{~cm}^{-1}$; ${ }^{1} \mathrm{H}$ NMR (DMSO-d $6,400 \mathrm{MHz}, \delta$ ppm): 8.05 (1H, d, J=1.2 Hz, H-9), $7.92(1 \mathrm{H}, \mathrm{s}, \mathrm{H}-12), 7.86(1 \mathrm{H}, \mathrm{s}, \mathrm{H}-$ 15), $7.631(2 \mathrm{H}, \mathrm{t}, J=0.8 \mathrm{~Hz}, \mathrm{H}-4,3), 7.221(1 \mathrm{H}, \mathrm{d}, J=7.2 \mathrm{~Hz}, \mathrm{H}-5), 6.590$ $(1 \mathrm{H}, \mathrm{m}, \mathrm{H}-10), 5.16(2 \mathrm{H}, \mathrm{s}, \mathrm{H}-17), 1.68(1 \mathrm{H}, \mathrm{s}$, quinolin-4-yl] methanol-OH proton); ${ }^{13} \mathrm{C}$ NMR (DMSO- $d_{6}, 100 \mathrm{MHz}, \delta \mathrm{ppm}$ ): 152.9 (C, C-14), 148.6 (C, C-2), 148.4 (C, C-6), 145.8 (C, C-8), 131.1 (CH, C5), 130.5 (C, C-11), 130.2 (CH, C-10), 125.3 (CH, C-9), 122.7 (C, C-13), 114.8 (CH, C-12), $112.6(\mathrm{CH}, \mathrm{C}-15), 110.7(\mathrm{CH}, \mathrm{C}-4), 59.7\left(\mathrm{CH}_{2}, \mathrm{C}-\right.$ 17).Calcd. $259.68 \mathrm{gm} / \mathrm{mol}$. EI-MS (m/z): $260.0(\mathrm{M}+1)$.

\section{[6-bromo-2-(furan-2-yl) quinolin-4-yl] methanol (10b)}

Yield: 83 \%. M. Pt. $151-153{ }^{\circ} \mathrm{C}$; IR (KBr) $\nu_{\max } 3215$ (-O-H stretching), 2923, 1670, 1603, $1248 \mathrm{~cm}^{-1}$; ${ }^{1} \mathrm{H}$ NMR (DMSO- $d_{6}, 400 \mathrm{MHz}, \delta \mathrm{ppm}$ ): $8.022(1 \mathrm{H}, \mathrm{d}, J=0.7 \mathrm{~Hz}, \mathrm{H}-9), 7.98(1 \mathrm{H}, \mathrm{d}, J=8 \mathrm{~Hz}, \mathrm{H}-15), 7.90(1 \mathrm{H}, \mathrm{s}, \mathrm{H}-$ 12), $7.740(1 \mathrm{H}, \mathrm{d}, J=2.4 \mathrm{~Hz}, \mathrm{H}-5), 7.630(1 \mathrm{H}, \mathrm{d}, J=1.2 \mathrm{~Hz}, \mathrm{H}-10), 7.21$ (1H, d, J=4 Hz, H-3), 6.58 (1H, m, H-4), 5.14 (2H, s, H-17), 1.67 (1H, s, quinolin-4-yl] methanol-OH proton); ${ }^{13} \mathrm{C}$ NMR (DMSO- $d_{6,}, 100 \mathrm{MHz}, \delta$ ppm): 152.9 (C, C-14), 148.6 (C, C-2), 148.2 (C, C-6), 145.9 (CH, C-5), 132.7 (CH, C-10), 131.2 (CH, C-9), 125.9 (CH, C-12), 125.8 (CH, C-11), 
119.1 (CH, C-15), 114.7 (C, C-13), 112.6 (CH, C-3), 110.8 (CH, C-4), $59.7\left(\mathrm{CH}_{2}, \mathrm{C}-17\right)$. Calcd. $304.13 \mathrm{gm} / \mathrm{ml}$. EI-MS (m/z): $304.13\left(\mathrm{M}^{+}\right)$.

\section{[8-fluoro-2-(furan-2-yl) quinolin-4-yl] methanol (10c)}

Yield: 82 \%. M. Pt. $85-87^{\circ} \mathrm{C}$; IR (KBr) $v_{\max } 3112$ (-0-H stretching), 2921, $1603,1250 \mathrm{~cm}^{-1} ;{ }^{1} \mathrm{H}$ NMR (DMSO- $d_{6}, 400 \mathrm{MHz}, \delta \mathrm{ppm}$ ): $7.89(1 \mathrm{H}, \mathrm{s}, \mathrm{H}-$ 15), $7.60(2 \mathrm{H}, \mathrm{t}, J=4 \mathrm{~Hz}, \mathrm{H}-11,4), 7.36(2 \mathrm{H}, \mathrm{d}, J=4 \mathrm{~Hz}, \mathrm{H}-10,12), 6.58$ $(1 \mathrm{H}, \mathrm{d}, \mathrm{J}=4 \mathrm{~Hz}, \mathrm{H}-3), 5.15$ (2H, s, H-17), 1.66 (1H, s, quinolin-4-yl] methanol-OH proton); ${ }^{13} \mathrm{C}$ NMR (DMSO- $\left.d_{6}, 100 \mathrm{MHz}, \delta \mathrm{ppm}\right): 158.6(\mathrm{C}$, C-14), 156.1 (C, C-9), 153.0 (C, C-2), 149.0 (CH, C-5), 148.3 (C, C-8), 145.1 (CH, C-11), 137.3 (C, C-13), 126.1 (CH, C-12), 119.4 (CH, C-15), 114.5 (CH, C-10), 113.8 (C, C-6), 112.6 (CH, C-3), 110.9 (CH, C-4), 59.7 $\left(\mathrm{CH}_{2}, \mathrm{C}-17\right)$. Calcd. $243.23 \mathrm{gm} / \mathrm{ml}$. EI-MS $(\mathrm{m} / \mathrm{z}): 244.10(\mathrm{M}+1)$.

\section{[6-chloro-2-(5-methylfuran-2-yl) quinolin-4-yl] methanol (10d)}

Yield: 77 \%. M. Pt. 136-138 ${ }^{\circ} \mathrm{C}$; IR (KBr) $v_{\max } 3186$ (-O-H stretching), 2897, 1672, 1607, 1245, $752 \mathrm{~cm}^{-1}$; ${ }^{1} \mathrm{H}$ NMR (DMSO-d $600 \mathrm{MHz}, \delta$ ppm): $8.03(1 \mathrm{H}, \mathrm{d}, \mathrm{J}=8 \mathrm{~Hz}, \mathrm{H}-10), 7.83$ (2H, d, J=4 Hz, H-11, 13), 7.59 $(1 \mathrm{H}, \mathrm{d}, \mathrm{J}=4 \mathrm{~Hz}, \mathrm{H}-16), 7.12(1 \mathrm{H}, \mathrm{d}, \mathrm{J}=4 \mathrm{~Hz}, \mathrm{H}-3), 6.191(1 \mathrm{H}, \mathrm{d}, \mathrm{J}=0.8 \mathrm{~Hz}$, $\mathrm{H}-4), 5.14$ (2H, s, H-18), 2.46 (3H, s, H-6), 1.81 (1H, s, quinolin-4-yl] methanol-OH proton); ${ }^{13} \mathrm{C}$ NMR (DMSO- $\mathrm{d}_{6}, 100 \mathrm{MHz}, \delta \mathrm{ppm}$ ): $154.4(\mathrm{C}$, C-15), 151.5 (C, C-7), 148.1 (C, C-5), 145.8 (C, C-2), 131.0 (C, C-9), 130.2 (C, C-12), 130.0 (CH, C-10), 125.1 (CH, C-11), 122.7 (C, C-14), 114.6 (CH, C-13), 112.1 (CH, C-16), 109.0 ( $\mathrm{CH}, \mathrm{C}-3,4), 59.7\left(\mathrm{CH}_{2}, \mathrm{C}-18\right)$, $13.6\left(\mathrm{CH}_{3}, \mathrm{C}-6\right)$.Calcd. $273.71 \mathrm{gm} / \mathrm{ml}$. EI-MS (m/z): $274.08(\mathrm{M}+1)$.

[6-bromo-2-(5-methylfuran-2-yl) quinolin-4-yl] methanol (10e)

Yield: $81 \%$. M. Pt. $104-106^{\circ} \mathrm{C}$; IR (KBr) $v_{\max } 3206$ (-O-H stretching), 2922, 1667, 1535, $1245 \mathrm{~cm}^{-1} ;{ }^{1} \mathrm{H}$ NMR (DMSO- $d_{6}, 400 \mathrm{MHz}, \delta \mathrm{ppm}$ ): $7.970(1 \mathrm{H}, \mathrm{d}, J=2 \mathrm{~Hz}, \mathrm{H}-10), 7.93(1 \mathrm{H}, \mathrm{d}, J=8 \mathrm{~Hz}, \mathrm{H}-11), 7.77(1 \mathrm{H}, \mathrm{s}, \mathrm{H}-$ 13), $7.701(1 \mathrm{H}, \mathrm{d}, J=2 \mathrm{~Hz}, \mathrm{H}-16), 7.09(1 \mathrm{H}, \mathrm{d}, J=4 \mathrm{~Hz}, \mathrm{H}-4), 6.181(1 \mathrm{H}$, d, J=0.8 Hz, H-4), 5.09 (2H, s, H-18), 2.45 (3H, s, H-6), $1.93(1 \mathrm{H}, \mathrm{s}$, quinolin-4-yl] methanol-OH proton); ${ }^{13} \mathrm{C}$ NMR (DMSO- $d_{6}, 100 \mathrm{MHz}, \delta$ ppm): 154.4 (C, C-15), 151.4 (C, C-5), 148.6 (C, C-7), 147.9 (C, C-2), 146.0 (C, C-9), 132.6 (C, C-12), 131.1 (CH, C-11), 125.8 (CH, C-10), 125.6 (C, C-14), 118.8 (CH, C-13), 114.6 (CH, C-16), 112.1 (CH, C-4), 109.0 (CH, C-3), $59.7\left(\mathrm{CH}_{2}, \mathrm{C}-18\right), 13.5\left(\mathrm{CH}_{3}, \mathrm{C}-6\right)$. Calcd. 318.16 gm/ml. EI-MS $(m / z): 318.04\left(\mathrm{M}^{+}\right)$.

\section{[8-fluoro-2-(5-methylfuran-2-yl) quinolin-4-yl] methanol (10f)}

Yield: 78 \%. M. Pt. $118-120^{\circ} \mathrm{C}$; IR (KBr) $v_{\max } 3332$ (-O-H stretching), 2922, 1599, $1247 \mathrm{~cm}^{-1} ;{ }^{1} \mathrm{H}$ NMR (DMSO- $d_{6}, 400 \mathrm{MHz}, \delta \mathrm{ppm}$ ): 7.76 (1H, s, H-16), $7.52(1 \mathrm{H}, \mathrm{t}, J=4 \mathrm{~Hz}, \mathrm{H}-12), 7.30(2 \mathrm{H}, \mathrm{m}, \mathrm{H}-13,3), 7.13$ $(1 \mathrm{H}, \mathrm{d}, J=4 \mathrm{~Hz}, \mathrm{H}-4), 6.16(1 \mathrm{H}, \mathrm{d}, J=4 \mathrm{~Hz}, \mathrm{H}-11), 5.10$ (2H, s, H-18), $2.42(3 \mathrm{H}, \mathrm{s}, \mathrm{H}-6), 1.81$ (1H, s, quinolin-4-yl] methanol-OH proton); ${ }^{13} \mathrm{C}$ NMR (DMSO- $\left.d_{6,}, 100 \mathrm{MHz}, \delta \mathrm{ppm}\right): 158.6$ (C, C-15), 154.4 (C, C-7), 151.5 (C, C-5), 148.7 (C, C-9), 148.3 (C, C-2), 125.9 (CH, C-12), 125.5 (C, C-10), 119.3 (CH, C-11), 114.9 (C, C-14), 113.9 (CH, C-13), 113.7 (CH, C-16), 112.2 (CH, C-4), $109.0(\mathrm{CH}, \mathrm{C}-3), 59.7\left(\mathrm{CH}_{2}, \mathrm{C}-18\right), 13.6$ $\left(\mathrm{CH}_{3}, \mathrm{C}-6\right)$. Calcd. $257.25 \mathrm{gm} / \mathrm{ml}$. EI-MS $(\mathrm{m} / \mathrm{z}): 358.00(\mathrm{M}+1)$.

\section{Pharmacokinetic parameter studies}

\section{ADME-toxicity prediction}

The molecular descriptors of synthesized compounds (4a-c, 5a-c and 10a-f) are predicted by pharmacokinetics parameters like absorption, distribution, metabolism, excretion and toxicity (ADMET). The ADMET/SAR [38] helps to evaluate biologically active molecules and eliminate a biologically poor molecule, an active lead molecule which contains undesirable functional groups based on Lipinski rule. The statistical calculation for lead molecules includes surface area, geometry and fingerprint properties which help to understand biological important endpoints. Aqueous solubility (PlogS), bloodbrain barrier penetration (QlogBB), intestinal absorption (logHIA) [39] and hepatotoxicity, Caco-2 cell permeability (QPPCaco) also help to predict the toxicity of lead molecules with intraperitoneal, oral, intravenous and subcutaneous toxic effects. The in silico study enables to decide the safety and efficacy of active molecules take up the molecule for in-depth studies.

\section{Calculation of pharmacokinetic parameters and toxicity potential}

Chemical structures and SMILES notations of the title compounds were obtained by using ACD labs Chem sketch version 12.0. SMILES notations of the derivatives were then fed in the online free version 2011.06 to calculate various molecular properties and to predict the bioactivity score for drug targets including enzymes and nuclear receptors, kinase inhibitors, GPCR ligands and ion channel modulators. Molecular properties such as partition coefficient (Log P), topological polar surface area (TPSA), hydrogen bond donors and acceptors, rotatable bonds, number of atoms, molecular weight, and violations of Lipinski's rule of five were calculated to evaluate the drug-likeness of the synthesized compounds [40]. The bioactivity score and drug-likeness properties of the title compounds were compared with the standard drugs streptomycin, ciprofloxacin and pyrazinamide respectively.

\section{Biological evaluation \\ DPPH free radical scavenging assay}

The assay was performed after modification of the method described by Blois [41]. $0.1 \mathrm{ml}$ of different concentrations of amethanolic solution of standard and test compounds $(0.5,0.75,1.0$, 1.25 and $1.5 \mathrm{mg} / \mathrm{ml}$ ) was added to $2 \mathrm{ml}$ of DPPH methanolic solution $(60 \mathrm{~mm})$. The mixture was shaken vigorously and allowed to react at room temperature and in darkness for $5 \mathrm{~h}$. The absorbance of the resulting solution was measured at $517 \mathrm{~nm}$ using a UV/Vis spectrophotometer after $5 \mathrm{~h}$ incubation. Scavenging of DPPH free radicals was calculated as:

\section{DPPH scavenging activity $(\%)=[(\mathrm{Ac}-\mathrm{At}) / \mathrm{Ac}] \times 100$}

Where Ac is the absorbance of the control tube (containing all reagents except the test compound), and At is the absorbance of the test tube. Ascorbic acid was used as the standard in the concentration range of $0.5-1.5 \mathrm{mg} / \mathrm{ml}$.

\section{Hydrogen peroxide scavenging assay}

$\mathrm{H}_{2} \mathrm{O}_{2}$ scavenging power was determined according to the method of Ruch and co-workers [42]. The method is based on the ability of a compound to convert hydrogen peroxide to water. $40 \mathrm{~mm}$ solution of hydrogen peroxide was prepared in saline phosphate buffer ( $\mathrm{pH} 7.4)$. $100 \mu \mathrm{l}$ DMSO solutions of the test compounds or standards at the concentrations of $0.5,0.75,1.0,1.25$ and $1.5 \mathrm{mg} / \mathrm{ml}$ were separately added to $2 \mathrm{ml}$ of the prepared hydrogen peroxide solution and the absorbance was measured at $230 \mathrm{~nm}$ after 10 min against a blank solution. The hydrogen peroxide scavenging activity for compounds and standards was calculated using the following equation

$$
\mathrm{H}_{2} \mathrm{O}_{2} \text { scavenging activity }(\%)=[(\mathrm{Ac}-\mathrm{At}) / \mathrm{Ac}] \times 100
$$

Where Ac is the absorbance of the control and At is the absorbance of the tested compounds or standards. Ascorbic acid at the concentration range of $0.5-1.5 \mathrm{mg} / \mathrm{ml}$ was used as the standard.

\section{Antibacterial activity}

\section{Cup plate method}

The antibacterial activity of synthesized molecules was studied systematically against three different strains of bacteria such as $E$. coli (ATCC No. 25922), K. pneumonia (ATCC No. 700603) and $S$. typhimurium (ATCC No. 14028) (gram-negative) by the agar diffusion method [43-45]. The organisms were subcultured using nutrient agar medium. The tubes containing sterilized medium were inoculated with respective bacterial strain. After incubation at $37 \pm 1$ ${ }^{\circ} \mathrm{C}$ for $24 \mathrm{~h}$. They were stored in a refrigerator. The flasks with incubated bacterial inoculums were prepared by transferring a loopful of stock culture to nutrient broth $(100 \mathrm{ml})$ and incubated at $37 \pm 1{ }^{\circ} \mathrm{C}$ for $18 \mathrm{~h}$. Before the experimentation, solutions of the test compounds were prepared by dissolving $2 \mathrm{ml}$ each in dimethyl sulphoxide $(5 \mathrm{ml})$. Reference standards for gram-negative bacteria were made by dissolving accurately weighed the quantity of Streptomycin respectively in dimethyl sulphoxide solution, separately. The nutrient agar medium was sterilized by autoclave at $121^{\circ} \mathrm{C}(15 \mathrm{lb} / \mathrm{sq}$. inch $)$.

The petri-plates, test tubes and flasks containing medium is plugged with cotton were sterilized in hot air-oven at $160{ }^{\circ} \mathrm{C}$, for an hrs. Into each sterilized pertained plate $(10 \mathrm{~cm}$ diameter $)$, about $20 \mathrm{ml}$ each of molten nutrient bacteria $(6 \mathrm{ml}$ of inoculums to $300 \mathrm{ml}$ of nutrient 
agar medium) was transferred, aseptically. The plates were left at room temperature to allow for solidification. On each plate, four cups of $6 \mathrm{~mm}$ diameter were made with a sterile cork borer. Then, $0.1 \mathrm{ml}$ of the test solution was added to the cups, aseptically and labelled, accordingly. The plates were kept undisturbed for at least 2 h. at room temperature to allow diffusion of the solution properly, into the nutrient agar medium. All the experiments were carried out in triplicate. Simultaneously, controls were maintained employing $0.1 \mathrm{ml}$ of dimethyl sulphoxide to observe the solvent effects. After incubation of the plates at $37 \pm 1^{\circ} \mathrm{C}$ for $24 \mathrm{~h}$, the diameter of the zone of inhibition was read with the help of antibiotic zone scale.

\section{Antifungal activity}

Poisoned food technique was performed to investigate the antifungal effect of test compounds against Aspergillusflavus and Cryptococcus neoformans. Synthesized compounds were tested for their antifungal activity [46]. The fungi employed for screening were sub-cultured using potato dextrose agar medium. The potatodextrose-agar medium was sterilized by autoclave at $121{ }^{\circ} \mathrm{C}(15$ $\mathrm{lb} / \mathrm{sq}$. inch), for $15 \mathrm{~min}$. The petri-plates, tubes and flasks plugged with cotton were sterilized in an autoclave at $121^{\circ} \mathrm{C}$, for an hour. Into each sterilized petri-plate $(10 \mathrm{~cm}$ diameter $)$, about $30 \mathrm{ml}$ each of molten potato dextrose-agar medium inoculated with the respective fungus ( $5 \mathrm{~mm}$ disc of the fungus grown) was transferred, aseptically. The petri dishes were incubated at $28 \pm 1^{\circ} \mathrm{C}$ temperature. The diameter of the zone of inhibition was read with the help of an 'antibiotic zone reader'. The experiments were performed in triplicate in order to minimize the errors. The inhibition percentage of the A. flavusand $C$. neoformansmycelial growth was calculated using the following formula.

IP $=100 \times$ CT

Where $\mathrm{C}$ is the average of 3 replicates of mycelial growth $(\mathrm{cm})$ of control petri dishes and $\mathrm{T}$ is the average of 3 replicates of mycelial growth $(\mathrm{cm})$ of treated petri dishes. Fluconazole was used as the positive control and DMSO was thus used as the negative control.

\section{RESULTSANDDISCUSSION}

\section{Chemistry}

The synthesis of key intermediate 1-(1-benzofuran-2-yl) ethanone (1) and its utilization in the construction of 2-(1-benzofuran-2-yl) quinoline-4-carboxylic acids 3(a-c) and 8(a-f) are shown in SchemeI, II and table 1 . The intermediate (1) was synthesized by stirring a mixture of 2-hydroxybenzaldehyde with chloroacetone inbasic medium using methanol as solvent. Subsequently, 2-(1-benzofuran2-yl) quinoline-4-carboxylic acids $3(\mathrm{a}-\mathrm{c})$ were synthesized by the reaction of a compound (1) with substituted isatins $2(a-c)$ in basic medium to obtain the products $3(\mathrm{a}-\mathrm{c})$. The ester, methyl 2-(1benzofuran-2-yl) quinoline-4-carboxylates 4(a-c) were synthesized by reacting 3(a-c) with methyl alcohol in the presence of catalytic amount of Conc. $\mathrm{H}_{2} \mathrm{SO}_{4}$ to obtain the product in good yield. The alcohol 5(a-c) was synthesized by the reaction of compound 4(a-c) with reducing agent sodium borotetrahydride, under stirring condition.

Table 1: Particulars of the derivatives of [2-(1-benzofuran-2-yl) quinolin-4-yl] methanol and [2-(1-furan-2-yl) quinolin-4-yl] methanol

\begin{tabular}{|c|c|c|c|c|c|c|c|}
\hline S. No. & Samples code & $\mathbf{R}$ & & Molecular formula & Molecular weight & (\%)yield & Melting point $\left({ }^{\circ} \mathrm{C}\right)$ \\
\hline 1 & $4 a$ & $-\mathrm{H}-$ & & $\mathrm{C}_{19} \mathrm{H}_{13} \mathrm{NO}_{3}$ & 303.31 & 83 & $115-118$ \\
\hline 2 & $4 \mathrm{~b}$ & $-\mathrm{Cl}$ & & $\mathrm{C}_{19} \mathrm{H}_{12} \mathrm{ClNO}_{3}$ & 337.75 & 85 & $125-128$ \\
\hline 3 & $4 c$ & $-F$ & & $\mathrm{C}_{19} \mathrm{H}_{12} \mathrm{FNO}_{3}$ & 301.30 & 80 & $122-124$ \\
\hline 4 & $5 a$ & $-\mathrm{H}-$ & & $\mathrm{C}_{18} \mathrm{H}_{13} \mathrm{NO}_{2}$ & 275.30 & 78 & $154-156$ \\
\hline 5 & $5 b$ & $-\mathrm{Cl}$ & & $\mathrm{C}_{18} \mathrm{H}_{12} \mathrm{ClNO}_{2}$ & 309.00 & 81 & $206-208$ \\
\hline \multirow[t]{2}{*}{6} & $5 c$ & $-F$ & & $\mathrm{C}_{18} \mathrm{H}_{12} \mathrm{FNO}_{2}$ & 293.00 & 79 & $158-160$ \\
\hline & & $\mathrm{R}$ & $\mathrm{R}_{1}$ & & & & \\
\hline 7 & $10 \mathrm{a}$ & $-\mathrm{H}-$ & $-\mathrm{Cl}$ & $\mathrm{C}_{14} \mathrm{H}_{10} \mathrm{ClNO}_{2}$ & 259.68 & 88 & $148-150$ \\
\hline 8 & $10 \mathrm{~b}$ & $-\mathrm{H}$ & $-\mathrm{Br}$ & $\mathrm{C}_{14} \mathrm{H}_{10} \mathrm{BrNO}_{2}$ & 304.13 & 83 & $151-153$ \\
\hline 9 & $10 \mathrm{c}$ & $-\mathrm{H}-$ & $-F$ & $\mathrm{C}_{14} \mathrm{H}_{10} \mathrm{FNO}_{2}$ & 243.23 & 82 & $85-87$ \\
\hline 10 & $10 \mathrm{~d}$ & $-\mathrm{CH}_{3}$ & $-\mathrm{Cl}$ & $\mathrm{C}_{15} \mathrm{H}_{12} \mathrm{ClNO}_{2}$ & 273.71 & 77 & $136-138$ \\
\hline 11 & $10 \mathrm{e}$ & $-\mathrm{CH}_{3}$ & $-\mathrm{Br}$ & $\mathrm{C}_{15} \mathrm{H}_{12} \mathrm{BrNO}_{2}$ & 318.16 & 81 & $104-106$ \\
\hline 12 & $10 \mathrm{f}$ & $-\mathrm{CH}_{3}$ & $-F$ & $\mathrm{C}_{15} \mathrm{H}_{12} \mathrm{FNO}_{2}$ & 257.25 & 78 & $118-120$ \\
\hline
\end{tabular}

IR spectra of the compounds showed an absorption band in the range of $3114 \mathrm{~cm}^{-1}$ due to the characteristic-OH group stretching. The ${ }^{1} \mathrm{H}$ NMR spectra of 5 a showed a singlet at $\delta 5.25 \mathrm{ppm}$ corresponding to methyl protons of [quinolin-4-yl] methanol, shown a singlet at $\delta 1.72 \mathrm{ppm}$ corresponding to alcohol proton of methyl alcohol and the remaining peaks which appeared at $\delta 8.20$ to 7.26 ppm corresponding to aromatic protons of the quinoline and benzofuran rings. The ${ }^{13} \mathrm{C}-\mathrm{NMR}$ spectra of 5 a showed a characteristic peak at $\delta 67.0 \mathrm{ppm}$ corresponding to the methyl carbon of [quinolin- 4-yl] methanol, and the peaks between $\delta 159.1$ to $108.5 \mathrm{ppm}$ corresponding to aromatic carbons. MS analysis of $5(\mathrm{a}-\mathrm{c})$ displayed their corresponding molecular ion peak confirming their molecular weight. IR spectra of the compounds showed the absorption band at $3215 \mathrm{~cm}^{-1}$ characteristic of- $\mathrm{OH}$ is stretching for different alcohols. The ${ }^{1} \mathrm{H}$ NMR spectra of $10 \mathrm{a}$ showed a singlet at $\delta 5.16 \mathrm{ppm}$ corresponding to methyl protons of [quinolin-4-yl] methanol, and another singlet at $\delta 1.68 \mathrm{ppm}$ corresponding to the alcohol proton of [quinolin-4-yl] methanol.

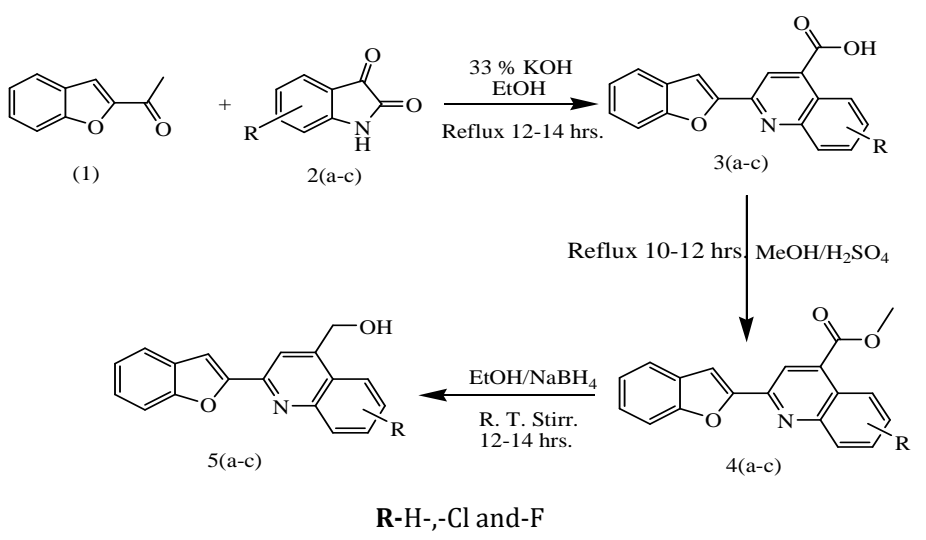

Scheme I: Synthesis of substituted [2-(1-benzofuran-2-yl) quinolin-4-yl] methanol 5(a-c) 


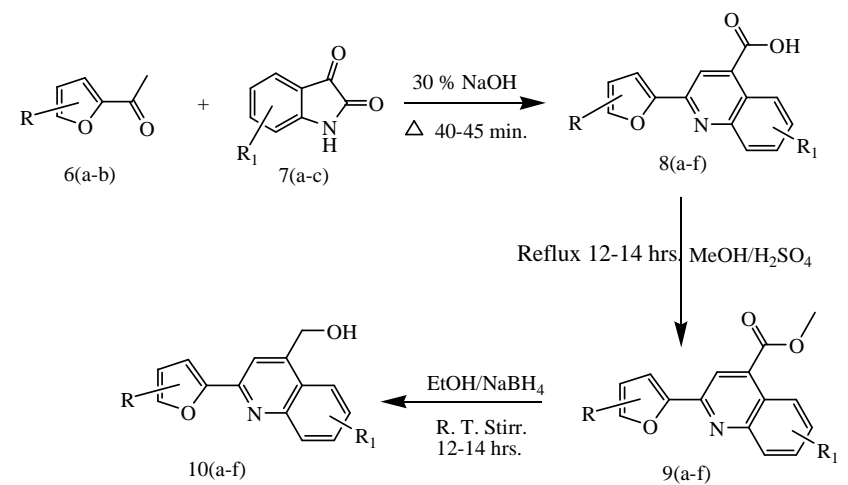

\begin{tabular}{ll}
\hline $\mathbf{R}$ & $\mathbf{R} \mathbf{1}$ \\
\hline$-\mathrm{H}-$ & $-\mathrm{Cl}$ \\
$-\mathrm{H}-$ & $-\mathrm{Br}$ \\
$-\mathrm{H}-$ & $-\mathrm{F}$ \\
$-\mathrm{CH}_{3}$ & $-\mathrm{Cl}$ \\
$-\mathrm{CH}_{3}$ & $-\mathrm{Br}$ \\
$-\mathrm{CH}_{3}$ & $-\mathrm{F}$ \\
\hline
\end{tabular}

Scheme II: Synthesis of substituted [2-(1-furan-2-yl) quinolin-4-yl] methanol 10(a-f)

The peaks between $\delta 8.08$ to 6.59 ppm corresponding to benzofuran and quinoline ring protons. The ${ }^{13} \mathrm{C}$-NMR spectra of $10 \mathrm{a}$ showed a peak at $\delta 59.7$ ppm corresponding to the methyl carbon of [quinolin4-yl] methanol, and the peaks between $\delta 152.9$ to $110.7 \mathrm{ppm}$ corresponding to aromatic carbons. MS analysis of $10 \mathrm{a}$ displayed the molecular ion peak confirming their molecular weight. The ${ }^{1} \mathrm{H}$ NMR spectra of $10 \mathrm{~d}$ showed a singlet at $\delta 5.14 \mathrm{ppm}$ corresponding to methyl protons of [quinolin-4-yl] methanol, it showed singlet at $\delta$ $2.46 \mathrm{ppm}$ corresponding to furan substituted methyl protons and appeared a singlet at $\delta 1.81 \mathrm{ppm}$ corresponding to the alcohol proton of [quinolin-4-yl] methanol and the aromatic peaks which appeared between $\delta 8.05$ to $6.19 \mathrm{ppm}$. The ${ }^{13} \mathrm{C}$-NMR spectra of $10 \mathrm{~d}$ showed a peak at $\delta 59.7 \mathrm{ppm}$ corresponding to the methyl carbon of [quinolin-4-yl] methanol, peak at $\delta 13.6 \mathrm{ppm}$ corresponding to the methyl carbon of furan substituted methyl and the peaks between $\delta$ 154.4 to 109.0 ppm corresponding to aromatic carbons.

\section{In silico ADMET (Absorption, distribution, metabolism,} excretion and toxicity) profile

The compounds with poor bioavailability show less effectiveness against disease. To overcome this problem, predicting bioavailability properties will be of great advantage in drug development. Hence, using computerbased methods like ADMET and SAR tools the molecular descriptors and drug likeliness properties was studied. The pharmacokinetic properties are represented in table 2 and 3. The in silico data of all the molecules displayed are within acceptable range. The interpretation of test compounds with reference standards (streptomycin, fluconazole and ascorbic acid) show that the compounds $4 a-c, 5 a-c$ and 10a-f were in good, acceptable range and hence, further used to make an oral formulation for absorption and to transport proteins and metabolizing enzymes to maintain homeostatic condition. The intestinal absorption $\left(\log _{\mathrm{HIA}}\right)$ and Caco-2 cell permeability (PCaco-2) within the range of-2 poor absorption and +2 more absorption reveal that the compounds are more permeable in the intestine and helps for good transport of the drug or its metabolites.

The reference range of -5 (poor) to +1 (good) and substrate inhibitor from 0 to 1 in which the reference and test compounds $4 a-c, 5 a-c$ and 10a-f shows significant activity with human intestinal absorption and metabolism. The aqueous solubility of compounds lies with a range of 0 (poor) to 2 (good) showed that all the molecules have good solubility. While the reference compound, as well as test compounds, came within the acceptable range (table 3).

The toxicity of the substituted [2-(1-benzofuran-2-yl) quinolin-4-yl] methanol and [2-(1-furan-2-yl) quinolin-4-yl] methanol was predicted. The probability of health effects was predicted using ACD/I-Lab 2.0 (guest). The toxicity of selected compounds was listed in table 2 . The $\mathrm{LD}_{50}$ of potential compounds detects the cumulative potential of acute toxicity that is administered through oral, subcutaneous, intra peritoneal, intravenous and subcutaneous on mouse models. The comparative analysis of reference compounds with test compounds on subcutaneous, intra-peritoneal, oral and intravenous is low when compared to the reference molecule. The toxicity results suggest that the compounds $4 a-c, 5 a-c$ and $10 a-f$ have less toxic effect to tissue and with no side effect (table 2). Hence, can be considered for further development.

Table 2: $\mathrm{LD}_{50}$ ADME-TOX parameters and probability of health effects of substituted [2-(1-benzofuran-2-yl) quinolin-4-yl] methanol and [2-(1-furan-2-yl) quinolin-4-yl] methanol using ACD/I-Lab 2.0

\begin{tabular}{|c|c|c|c|c|}
\hline Ligands & Intraperitoneal $^{a}$ & Oralb & Intravenous $^{c}$ & Subcutaneous $^{\mathrm{d}}$ \\
\hline $4 a$ & $490(0.45)$ & $540(0.15)$ & $55(0.49)$ & $490(0.28)$ \\
\hline $4 b$ & $500(0.4)$ & $450(0.18)$ & $56(0.48)$ & $550(0.33)$ \\
\hline $4 \mathrm{c}$ & $640(0.46)$ & $460(0.15)$ & $58(0.47)$ & $940(0.34)$ \\
\hline $5 a$ & $420(0.34)$ & $840(0.32)$ & $46(0.47)$ & $620(0.25)$ \\
\hline $5 b$ & $400(0.34)$ & $810(0.28)$ & $42(0.47)$ & $520(0.28)$ \\
\hline $5 c$ & $620(0.44)$ & $690(0.32)$ & $47(0.47)$ & $570(0.29)$ \\
\hline $10 \mathrm{a}$ & $260(0.43)$ & $800(0.25)$ & $65(0.4)$ & $470(0.38)$ \\
\hline $10 \mathrm{~b}$ & $280(0.36)$ & $870(0.34)$ & $67(0.35)$ & $770(0.33)$ \\
\hline $10 \mathrm{c}$ & $380(0.28)$ & $550(0.29)$ & $78(0.38)$ & $760(0.33)$ \\
\hline $10 \mathrm{~d}$ & $260(0.44)$ & $780(0.23)$ & $62(0.39)$ & $500(0.39)$ \\
\hline $10 \mathrm{e}$ & $250(0.37)$ & $840(0.34)$ & $59(0.35)$ & $720(0.34)$ \\
\hline $10 \mathrm{f}$ & $350(0.29)$ & $580(0.34)$ & $67(0.38)$ & $680(0.32)$ \\
\hline Streptomycin & $310(0.76)$ & $880(0.53)$ & $110(0.67)$ & $400(0.52)$ \\
\hline Fluconazole & $1200(0.73)$ & $1000(0.51)$ & $580(0.47)$ & $2700(0.23)$ \\
\hline Ascorbic acid & $1100(0.7)$ & $4500(0.61)$ & $820(0.58)$ & $2700(0.5)$ \\
\hline
\end{tabular}

Estimated $\mathrm{LD}_{50}$-mouse value in $\mathrm{mg} / \mathrm{kg}$ after Intraperitoneala, Oral ${ }^{\mathrm{b}}$, Intravenous ${ }^{\mathrm{c}}$ and Subcutaneous ${ }^{\mathrm{d}}$ administration, The drugs with amoderate effect on reliability index $(>0.5)$, The drugs with borderline effect on reliability index $(>0.3,<0.5)$. 
Table 3: ADME and pharmacological parameters prediction for the ligands substituted [2-(1-benzofuran-2-yl) quinolin-4-yl] methanol and [2-(furan-2-yl) quinolin-4-yl] methanol using ADMET/SAR

\begin{tabular}{|c|c|c|c|c|c|c|c|}
\hline Ligands & $P \operatorname{logBB}{ }^{a}$ & PCaco $^{\text {b }}$ & $\log \mathrm{HIA}^{\mathrm{c}}$ & logpGI (Non-substrate) ${ }^{\mathrm{d}}$ & logpGI (Non-inhibitor)e & $P \log S^{f}$ & logpappg \\
\hline $4 a$ & 0.9430 & 0.5416 & 1.0000 & 0.7113 & 0.9010 & -3.4558 & 1.0868 \\
\hline $4 b$ & 0.9656 & 0.5853 & 1.0000 & 0.7231 & 0.8397 & -4.3351 & 1.1113 \\
\hline $4 c$ & 0.9709 & 0.5732 & 1.0000 & 0.7055 & 0.7329 & -3.9795 & 1.1292 \\
\hline $5 a$ & 0.9866 & 0.5175 & 1.0000 & 0.7710 & 0.7075 & -2.8564 & 1.2208 \\
\hline $5 b$ & 0.9906 & 0.5510 & 1.0000 & 0.7642 & 0.8692 & -3.8706 & 1.2692 \\
\hline $5 c$ & 0.9931 & 0.5465 & 1.0000 & 0.7690 & 0.8247 & -3.4170 & 1.2863 \\
\hline $10 \mathrm{a}$ & 0.9906 & 0.5510 & 1.0000 & 0.7642 & 0.8692 & -3.8706 & 1.2692 \\
\hline $10 \mathrm{~b}$ & 0.9892 & 0.5277 & 1.0000 & 0.7637 & 0.8377 & -3.6714 & 1.2573 \\
\hline $10 c$ & 0.9931 & 0.5464 & 1.0000 & 0.7690 & 0.8247 & -3.4170 & 1.2863 \\
\hline $10 \mathrm{~d}$ & 0.9876 & 0.5621 & 1.0000 & 0.7598 & 0.8859 & -3.7943 & 1.2395 \\
\hline $10 \mathrm{e}$ & 0.9855 & 0.5388 & 1.0000 & 0.7568 & 0.8570 & -3.6238 & 1.2205 \\
\hline $10 \mathrm{f}$ & 0.9907 & 0.5559 & 1.0000 & 0.7609 & 0.8566 & -3.3745 & 1.2440 \\
\hline Streptomycin & 0.9712 & 0.8824 & 0.6968 & 0.5531 & 0.7577 & -2.0122 & -0.5128 \\
\hline Fluconazole & 0.9382 & 0.9894 & 0.8867 & 0.6008 & 0.8782 & -1.8626 & 1.3598 \\
\hline Ascorbic acid & 0.8532 & 0.7710 & 0.6559 & 0.8696 & 0.9347 & 0.1081 & -0.3148 \\
\hline
\end{tabular}

apredicted blood/brain barrier partion coefficient (1-high penetration, 2-medium penetration and 3-low penetration). bpredicted Caco-2 cell permeability in $\mathrm{nm} / \mathrm{s}$ (acceptable range- 1 is poor, +1 is great). ${ }^{c}$ predicted human intestinal absorption in nm/s (acceptable range 0 is poor, $>1$ is great). ${ }^{d}$ predicted P-glycoprotein Substrate in $\mathrm{nm} / \mathrm{s}$ (acceptable range of-5 is poor, 1 is great). epredicted P-glycoprotein inhibitor in nm/s (acceptable range 0-1). fpredicted aqueous solubility, (Concern value is 0-2 highly soluble). gpredicted Caco-2 cell Permeability in cm/s (Concern value is-1 to 1 ).

\section{Drug-likeness score of the entitled compounds}

Lipinski's rule of five is generally used by pharmaceutical chemists in drug design and development to predict bioavailability of lead or drug molecules. According to Lipinski's rule of five, a candidate molecule will likely be orally active, if: i) the calculated octanol/water partition coefficient $(\log P)<5$, ii) the molecular weight is under 500, iii) there were less than 5 hydrogen bond donors ( $\mathrm{OH}$ and $\mathrm{NH}$ groups) and, iv) there are less than ten hydrogen bond acceptors (notably $\mathrm{N}$ and 0 ). The molecular properties of [2-(1-benzofuran-2-yl) quinolin-4-yl] methanol and [2-(1-furan-2-yl) quinolin-4-yl] methanol derivatives (4a-c, 5a-c and $10 \mathrm{a}-\mathrm{f}$ ) were calculated and are represented in table 4. Compounds (4a, 4c, 5a-c and 10a-f) did not violate any of the Lipinski's rules of five and were expected to be orally active. Molecular hydrophobicity indicated by Log P values for all the title compounds except $4 \mathrm{~b}$ was found to be equal to 5 and it is in clear, non-violation of Lipinski's rule of five, suggesting poor membrane permeability across the cell. Partition coefficient values of streptomycin, ciprofloxacin and pyrazinamide, the standard drugs were found to be well under 5 justifying their oral use. Molecular weight of twelve furan quinoline derivatives was found to be less than 500 and thus, molecules are likely to be easily transported, diffused and absorbed as compared to large molecules. A number of hydrogen bond acceptors ( $\mathrm{O}$ and $\mathrm{N}$ atoms) and number of hydrogen bond donors ( $\mathrm{NH}$ and $\mathrm{OH})$ in the synthesized compounds $4 \mathrm{a}-\mathrm{c}, 5 \mathrm{a}-\mathrm{c}$ and $10 \mathrm{a}-\mathrm{fw}$-re in accordance with the Lipinski's rule of five i.e. less than 10 and 5, respectively. It can be predicted that the synthesized derivatives were likely to be orally active as they obeyed Lipinski's rule of five. The topological polar surface area is very much concurrently with the hydrogen bonding of a molecule and is a very good indicator bioavailability of drug molecules. TPSA of synthesized derivatives were observed in the range of 46.26-52.34 $\mathrm{A}^{\circ}$ and are well below the limit of $160 \mathrm{~A}^{\circ}$.

Table 4: Drug likeness score for the synthesized [2-(1-benzofuran-2-yl) quinolin-4-yl] methanol and [2-(1-furan-2-yl) quinolin-4-yl] methanol derivatives (4a-c, 5a-c and 10a-f)

\begin{tabular}{|c|c|c|c|c|c|c|c|c|}
\hline Compounds & miLog $\mathbf{P a}$ & TPSA $^{\mathbf{b}}$ & n-Atoms & $n-O N^{c}$ & n-OHNH ${ }^{d}$ & n-Violation & n-rotbe & $\mathbf{M W}^{\mathrm{f}}$ \\
\hline $4 a$ & 4.34 & 52.34 & 23 & 4 & 0 & 0 & 3 & 303.32 \\
\hline $4 b$ & 5.00 & 52.34 & 24 & 4 & 0 & 0 & 3 & 337.76 \\
\hline $4 c$ & 4.46 & 52.34 & 24 & 4 & 0 & 0 & 3 & 321.34 \\
\hline $5 a$ & 3.85 & 46.26 & 21 & 3 & 1 & 0 & 2 & 275.31 \\
\hline $5 b$ & 4.50 & 46.26 & 22 & 3 & 1 & 0 & 2 & 309.75 \\
\hline $5 c$ & 3.97 & 46.26 & 22 & 3 & 1 & 0 & 2 & 293.30 \\
\hline $10 \mathrm{a}$ & 3.20 & 46.26 & 18 & 3 & 1 & 0 & 2 & 259.69 \\
\hline $10 \mathrm{~b}$ & 3.33 & 46.26 & 18 & 3 & 1 & 0 & 2 & 304.14 \\
\hline $10 \mathrm{c}$ & 2.66 & 46.26 & 18 & 3 & 1 & 0 & 2 & 243.24 \\
\hline $10 \mathrm{~d}$ & 3.42 & 46.26 & 19 & 3 & 1 & 0 & 2 & 273.72 \\
\hline $10 \mathrm{e}$ & 3.55 & 46.26 & 19 & 3 & 1 & 0 & 2 & 318.17 \\
\hline $10 \mathrm{f}$ & 2.88 & 46.26 & 19 & 3 & 1 & 0 & 2 & 257.26 \\
\hline Ascorbic acid & -1.40 & 107.22 & 12 & 6 & 4 & 0 & 2 & 176.12 \\
\hline Streptomycin & -4.87 & 324.42 & 40 & 18 & 15 & 3 & 9 & 580.59 \\
\hline Fluconazole & -0.12 & 81.6 & 22 & 7 & 1 & 0 & 5 & 306.28 \\
\hline
\end{tabular}

\section{Antioxidant studies}

The antioxidant potential of synthesized compounds (4a-c, 5a-c and 10af) was determined as an index of pharmacological usefulness. Two in vitro models were used to evaluate antioxidant properties; radical scavenging and hydrogen peroxide scavenging activity. The antioxidant properties were expressed in terms of percentage inhibition and 50 percent inhibitory concentration $\left(\mathrm{IC}_{50}\right.$ ) values (table 5and6).

\section{DPPH radical scavenging assay}

The antioxidant potential of compounds (4a-c, 5a-c and 10a-f) was determined by in vitro model systems(Blois 1958) and were used for the evaluation of antioxidant properties, namely, 2, 2diphenyl-1-picrylhydrazyl (DPPH) radical scavenging activity and expressed in terms of $50 \%$ inhibitory concentration ( $\mathrm{IC}_{50}$ ) values (table 6). 
Table 5: Antioxidant activity of substituted [2-(1-benzofuran-2-yl) quinolin-4-yl] methanol and [2-(1-furan-2-yl) quinolin-4-yl] methanol derivatives (4a-c, 5a-c and 10a-f)

\begin{tabular}{lll}
\hline Compounds code & DPPH scavenging activity \% inhibition & $\mathbf{H}_{2} \mathbf{O}_{2}$ scavenging activity $\%$ inhibition \\
\hline $4 \mathrm{a}$ & $68 \pm 0.57$ & $64 \pm 1.0$ \\
$4 \mathrm{~b}$ & $71 \pm 1.0$ & $70 \pm 0.57$ \\
$4 \mathrm{c}$ & $82 \pm 1.52$ & $68 \pm 0.57$ \\
$5 \mathrm{a}$ & $65 \pm 1.52$ & $69 \pm 1.0$ \\
$5 \mathrm{~b}$ & $74 \pm 1.0$ & $70 \pm 2.5$ \\
$5 \mathrm{c}$ & $63 \pm 1.72$ & $58 \pm 1.0$ \\
$10 \mathrm{a}$ & $56 \pm 1.52$ & $52 \pm 3.02$ \\
$10 \mathrm{~b}$ & $46 \pm 1.0$ & $45 \pm 1.52$ \\
$10 \mathrm{c}$ & $85 \pm 1.52$ & $72 \pm 1.72$ \\
$10 \mathrm{~d}$ & $57 \pm 1.0$ & $52 \pm 0.57$ \\
$10 \mathrm{e}$ & $61 \pm 1.15$ & $64 \pm 1.52$ \\
$10 \mathrm{f}$ & $79 \pm 1.52$ & $69 \pm 2.64$ \\
Ascorbic acid & $96 \pm 1.15$ & $76 \pm 1.0$ \\
\hline
\end{tabular}

Values are expressed as mean $\pm \mathrm{SD}(\mathrm{n}=3)$. Values are significant with each other at $\mathrm{P}<0.05$ (Duncan's multiple range test).

The DPPH radical scavenging assay is one of the best free radicals scavenging mechanism (Scheme-III) by which antioxidant inhibits the oxidation and offer a rapid technique for screening the radical scavenging activity of specific compounds. All tested molecules exhibited a certain degree of radical scavenging activity. The compounds $4 \mathrm{c}, 5 \mathrm{~b}, 10 \mathrm{c}$ and $10 \mathrm{f}$ exhibited good radical scavenging potential (table 5) compared with standard, ascorbic acid.

\section{Hydrogen peroxide $\left(\mathrm{H}_{2} \mathrm{O}_{2}\right)$ scavenging capacity assay}

The hydrogen peroxide scavenging ability of synthesized derivatives was determined according to the method of Ruch and co-workers 1989 [42].

A solution of $\mathrm{H}_{2} \mathrm{O}_{2}(40 \mathrm{~mm})$ was prepared in phosphate buffer $(\mathrm{pH} 7.4)$

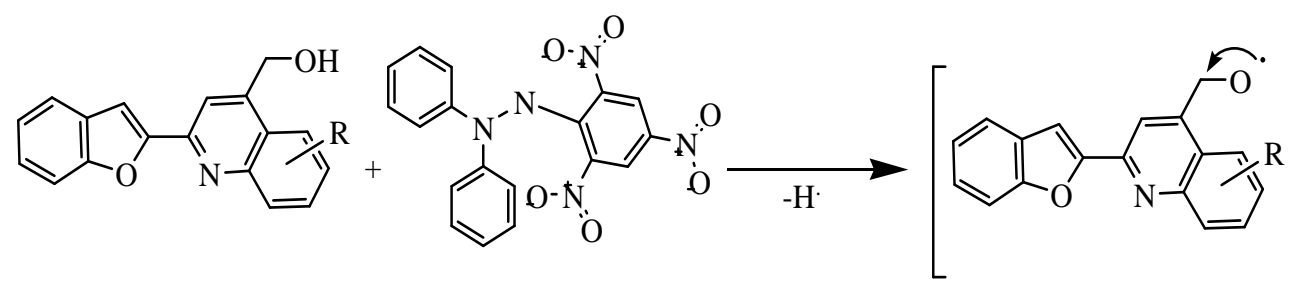<smiles></smiles>

Scheme III: The mechanism for the reaction of compounds 5a-c with DPPH radical

Table 6: $\mathrm{IC}_{50}(\mathrm{\mu g} / \mathrm{ml})$ values of DPPH and $\mathrm{H}_{2} \mathrm{O}_{2}$ scavenging activity of substituted [2-(1-benzofuran-2-yl) quinolin-4-yl] methanol and [2-(1furan-2-yl) quinolin-4-yl] methanol analogues (4a-c, 5a-c and 10a-f)

\begin{tabular}{|c|c|c|}
\hline Compounds code & DPPH scavenging activity $\mathrm{IC}_{50}(\mu \mathrm{g} / \mathrm{ml})$ & $\mathrm{H}_{2} \mathrm{O}_{2}$ scavenging activity $\mathrm{IC}_{50}(\mu \mathrm{g} / \mathrm{ml})$ \\
\hline $4 \mathrm{a}$ & $16.8 \pm 0.57$ & $16 \pm 1.52$ \\
\hline $4 b$ & $17.4 \pm 0.25$ & $15.5 \pm 0.20$ \\
\hline $4 \mathrm{c}$ & $20 \pm 1.0$ & $16 \pm 1.15$ \\
\hline $5 a$ & $16.5 \pm 0.2$ & $15 \pm 1.0$ \\
\hline $5 b$ & $18 \pm 1.15$ & $14.5 \pm 0.23$ \\
\hline $5 c$ & $16.5 \pm 0.2$ & $9.8 \pm 0.11$ \\
\hline $10 \mathrm{a}$ & $11.5 \pm 0.23$ & $11 \pm 0.20$ \\
\hline $10 \mathrm{~b}$ & $9.5 \pm 0.20$ & $8.2 \pm 1.15$ \\
\hline $10 \mathrm{c}$ & $24 \pm 0.57$ & $18 \pm 1.0$ \\
\hline $10 \mathrm{~d}$ & $12 \pm 1.52$ & $11.5 \pm 0.20$ \\
\hline $10 \mathrm{e}$ & $16 \pm 1.15$ & $15 \pm 1.52$ \\
\hline $10 \mathrm{f}$ & $13.8 \pm 0.15$ & $13.2 \pm 0.30$ \\
\hline Ascorbic acid & $6 \pm 1.52$ & $7.5 \pm 0.20$ \\
\hline
\end{tabular}

Values are expressed as mean $\pm \mathrm{SD}(\mathrm{n}=3)$. Values are significant with each other at $\mathrm{P}<0.05$ (Duncan's multiple range test). 
The solutions of different molecules $(10-50 \mu \mathrm{g} / \mathrm{ml})$ were prepared in phosphate buffer and were added to $\mathrm{H}_{2} \mathrm{O}_{2}$ solution $(0.6 \mathrm{ml}, 40 \mathrm{~mm})$. The absorbance value of the reaction mixture was recorded at $230 \mathrm{~nm}$. The blank solution contains phosphate buffer without $\mathrm{H}_{2} \mathrm{O}_{2}$. The percentage of an $\mathrm{H}_{2} \mathrm{O}_{2}$ scavenging of the entitled molecule and the standard compound was calculated as $\mathrm{H}_{2} \mathrm{O}_{2}$ radical scavenging activity.

$$
(\%)=[\{\text { Ao-A } 1 / \mathrm{Ao}\}] \times 100
$$

WhereAo is the absorbance of $\mathrm{H}_{2} \mathrm{O}_{2}$, A1 is the absorbance of $\mathrm{H}_{2} \mathrm{O}_{2}$ solution in the presence of benzofuran/furan quinolone methanols.
The compounds 4b, 5a, 10c and 10f exhibited good radical scavenging potential when compared with standard, ascorbic acid.

\section{Antibacterial activity}

The in vitro antibacterial activity of entitled compounds was determined by the agar well diffusion method. In this study, E. coli, $K$. pneumonia and S. typhirium (Gram-negative) were selected because of its infectious nature. The test compounds were dissolved in dimethyl sulfoxide (DMSO) at concentrations of 5 and $10 \mu \mathrm{g} / \mathrm{ml}$ (table 7).

Table 7: Antimicrobial activities of substituted [2-(1-benzofuran-2-yl) quinolin-4-yl] methanol and [2-(1-furan-2-yl) quinolin-4-yl] methanol analogues (4a-c, 5a-c and 10a-f)

\begin{tabular}{|c|c|c|c|c|c|c|}
\hline \multirow[t]{2}{*}{ Samples code } & \multicolumn{2}{|l|}{ E. coli } & \multicolumn{2}{|c|}{ K. pneumonia } & \multicolumn{2}{|c|}{ S. typhimurium } \\
\hline & $5 \mu \mathrm{g} / \mathrm{ml}$ & $10 \mu \mathrm{g} / \mathrm{ml}$ & $5 \mu \mathrm{g} / \mathrm{ml}$ & $10 \mu \mathrm{g} / \mathrm{ml}$ & $5 \mu \mathrm{g} / \mathrm{ml}$ & $10 \mu \mathrm{g} / \mathrm{m}$ \\
\hline $4 a$ & $2.4 \pm 0.14$ & $2.9 \pm 0.11$ & $3.2 \pm 0.08$ & $3.4 \pm 0.14$ & $2.5 \pm 0.11$ & $3.0 \pm 0.11$ \\
\hline $4 \mathrm{~b}$ & $2.6 \pm 0.17$ & $3.1 \pm 0.17$ & $2.8 \pm 0.12$ & $3.4 \pm 0.17$ & $2.3 \pm 0.12$ & $3.0 \pm 0.17$ \\
\hline $4 \mathrm{c}$ & $3.1 \pm 0.12$ & $3.5 \pm 0.21$ & $2.7 \pm 0.17$ & $3.6 \pm 0.26$ & $3.4 \pm 0.12$ & $3.6 \pm 0.31$ \\
\hline $5 a$ & $3.4 \pm 0.17$ & $3.9 \pm 0.12$ & $3.2 \pm 0.12$ & $3.6 \pm 0.26$ & $3.0 \pm 0.09$ & $3.4 \pm 0.20$ \\
\hline $5 b$ & $3.3 \pm 0.17$ & $3.6 \pm 0.18$ & $2.8 \pm 0.09$ & $3.5 \pm 0.22$ & $3.1 \pm 0.2$ & $3.6 \pm 0.12$ \\
\hline $5 c$ & $2.4 \pm 0.25$ & $3.0 \pm 0.18$ & $3.1 \pm 0.12$ & $3.4 \pm 0.08$ & $3.3 \pm 0.17$ & $3.8 \pm 0.35$ \\
\hline $10 a$ & $2.6 \pm 0.17$ & $3.4 \pm 0.26$ & $3.0 \pm 0.12$ & $3.5 \pm 0.12$ & $2.8 \pm 0.10$ & $3.3 \pm 0.17$ \\
\hline $10 \mathrm{~b}$ & $3.4 \pm 0.17$ & $3.6 \pm 0.12$ & $2.8 \pm 0.15$ & $3.2 \pm 0.12$ & $3.1 \pm 0.12$ & $3.4 \pm 0.21$ \\
\hline $10 c$ & $2.4 \pm 0.27$ & $2.8 \pm 0.18$ & $3.1 \pm 0.12$ & $3.3 \pm 0.18$ & $3.0 \pm 0.12$ & $3.5 \pm 0.17$ \\
\hline $10 \mathrm{~d}$ & $3.2 \pm 0.26$ & $3.5 \pm 0.09$ & $3.4 \pm 0.21$ & $3.8 \pm 0.35$ & $2.7 \pm 0.12$ & $2.9 \pm 0.12$ \\
\hline $10 \mathrm{e}$ & $2.7 \pm 0.31$ & $3.1 \pm 0.12$ & $3.2 \pm 0.20$ & $3.6 \pm 0.12$ & $3.4 \pm 0.22$ & $3.8 \pm 0.40$ \\
\hline $10 \mathrm{f}$ & $2.8 \pm 0.12$ & $3.4 \pm 0.12$ & $3.0 \pm 0.12$ & $3.6 \pm 0.25$ & $2.5 \pm 0.22$ & $3.0 \pm 0.08$ \\
\hline Streptomycin & $2.7 \pm 0.12$ & $3.8 \pm 0.09$ & $3.4 \pm 0.21$ & $3.6 \pm 0.26$ & $3 \pm 0.12$ & $3.5 \pm 0.18$ \\
\hline
\end{tabular}

Values are expressed as mean $\pm S D(n=3)$. Values are significant with each other at $\mathrm{P}<0.05$ (Duncan's multiple range test).

The results indicated that among the tested compounds, concerning antibacterial activities, compounds 4c, 5a-b, 10b 10d and $10 \mathrm{f}$ found to be potent against E. coli, while the compounds $4 \mathrm{a}-\mathrm{b}, 5 \mathrm{c}, 10 \mathrm{a}, 10 \mathrm{c}$ and 10 e shown significant activity. The compounds $4 \mathrm{a}, 5 \mathrm{a}$ and $10 \mathrm{c}-\mathrm{d}$ found to be potent against K. pneumonia, while the compounds $4 \mathrm{~b}-\mathrm{c}$, $5 \mathrm{~b}-\mathrm{c}, 10 \mathrm{a}-\mathrm{b}$ and $10 \mathrm{e}-\mathrm{f}$ shown moderate activity. The compounds $4 \mathrm{c}$, $5 \mathrm{a}$ and $10 \mathrm{c}-\mathrm{d}$ found to be possessed good inhibition against $S$. typhimurium, while the compounds $4 \mathrm{a}-\mathrm{b}, 5 \mathrm{~b}-\mathrm{c}, 10 \mathrm{a}-\mathrm{b}$ and $10 \mathrm{e}-\mathrm{f}$ shown significant activity as compared with standard drug streptomycin. From the results, it could be accomplished that, the chloro and fluoro functioned derivatives showed better activity than un-substituted derivatives against all bacterial strains.

\begin{abstract}
Antifungal activity
Further, the synthesized compounds were screened for their in vitro antifungal activity against $A$. flavusand $C$. reoformansbecause of their transmittable nature. The compounds were dissolved in DMSO and antifungal activity was determined by the poisoned food technique at concentrations of 50 and $100 \mu \mathrm{g} / \mathrm{ml}$.

The antifungal result data (table 8) indicated that the synthesized compounds showed a variable degree of inhibition against fungal species, the compounds $4 \mathrm{c}, 5 \mathrm{c}$ and $10 \mathrm{c}-\mathrm{e}$ showed potent activity against $A$. flavus, while the compounds $4 \mathrm{a}-\mathrm{b}, 5 \mathrm{a}-\mathrm{b}, 10 \mathrm{a}-\mathrm{b}$ and $10 \mathrm{f}$ have shown moderate activity.
\end{abstract}

Table 8: Antifungal activities of substituted [2-(1-benzofuran-2-yl) quinolin-4-yl] methanol and [2-(1-furan-2-yl) quinolin-4-yl] methanol analogues (4a-c, 5a-c and 10a-f)

\begin{tabular}{|c|c|c|c|c|}
\hline \multirow[t]{2}{*}{ Samples code } & \multicolumn{2}{|c|}{ A. flavus \% inhibition } & \multicolumn{2}{|c|}{ C. neoformans \% inhibition } \\
\hline & $50 \mu \mathrm{g} / \mathrm{ml}$ & $100 \mu \mathrm{g} / \mathrm{ml}$ & $50 \mu \mathrm{g} / \mathrm{ml}$ & $100 \mu \mathrm{g} / \mathrm{ml}$ \\
\hline $4 a$ & $36 \pm 1.52$ & $60 \pm 1.0$ & $54 \pm 1.52$ & $86 \pm 2.08$ \\
\hline $4 \mathrm{~b}$ & $45 \pm 1.52$ & $68 \pm 1.0$ & $56 \pm 3.5$ & $80 \pm 0.57$ \\
\hline $4 c$ & $56 \pm 1.0$ & $79 \pm 0.57$ & $36 \pm 1.15$ & $85 \pm 1.0$ \\
\hline $5 a$ & $42 \pm 1.52$ & $70 \pm 2.08$ & $48 \pm 1.52$ & $76 \pm 1.0$ \\
\hline $5 b$ & $47 \pm 1.0$ & $78 \pm 2.0$ & $54 \pm 1.15$ & $87 \pm 1.15$ \\
\hline $5 c$ & $56 \pm 1.52$ & $68 \pm 0.57$ & $41 \pm 1.0$ & $84 \pm 1.52$ \\
\hline $10 \mathrm{a}$ & $34 \pm 1.0$ & $65 \pm 1.52$ & $54 \pm 2.0$ & $90 \pm 1.52$ \\
\hline $10 \mathrm{~b}$ & $41 \pm 2.0$ & $70 \pm 1.15$ & $50 \pm 1.52$ & $86 \pm 3.0$ \\
\hline $10 c$ & $51 \pm 3.5$ & $68 \pm 2.0$ & $36 \pm 1.15$ & $71 \pm 2.08$ \\
\hline $10 \mathrm{~d}$ & $53 \pm 1.52$ & $74 \pm 2.0$ & $54 \pm 3.5$ & $86 \pm 3.0$ \\
\hline $10 \mathrm{e}$ & $57 \pm 1.0$ & $78 \pm 1.52$ & $68 \pm 0.57$ & $80 \pm 2.0$ \\
\hline $10 \mathrm{f}$ & $46 \pm 1.15$ & $82 \pm 2.0$ & $44 \pm 3.5$ & $74 \pm 1.73$ \\
\hline Fluconazole & $47 \pm 0.57$ & $64 \pm 2.3$ & $42 \pm 0.57$ & $75 \pm 0.57$ \\
\hline
\end{tabular}

Values are expressed as mean $\pm \mathrm{SD}(\mathrm{n}=3)$. Values are significant with each other at $\mathrm{P}<0.05$ (Duncan's multiple range test).

The compounds 4a-b, 5a-b, 10a-b and 10d showed good activity against C. reoformans, while the compounds 4c, 5c, 10c and $10 \mathrm{f}$ have showed significant activity when compared with standard drug fluconazole. The results exhibited that, the halogensubstituted derivatives showed better activity compared to other analogues.

\section{Statistical analysis}

The measurements were expressed as mean $\pm \mathrm{SD}$ for standard drugs. The data were analyzed using one-way analysis of variance (ANOVA) followed by Duncan's Multiple Range Test (DMRT) by using statistical package of social science (SPSS) version 10.0 for 
Windows. A difference in the mean values of $\mathrm{P}<0.05$ was considered to be statistically significant.

\section{CONCLUSION}

The present work reports the synthesis, spectral characterization and biological activities including antioxidant and antimicrobial activities of synthesized series of benzofuran/furan quinoline methanol analogues (table 1). Molecules were made to predict ADMET/SAR in silico, the synthesized molecules are in an acceptable range were further screened for antioxidant analysis with DPPH and $\mathrm{H}_{2} \mathrm{O}_{2}$ scavenger methods and antimicrobial activity. The work indicates that the entitled compounds were found to possess good antioxidant and potent antimicrobial activity. The potent molecules (4b-c, 5a-c, and 10b-f) will be further taken up for in detail study, by varying the functionalities on the aromatic rings with achange in carbon chain length, the electron donor and withdrawing groups. The furan quinolone methanols can be considered as lead moieties for drug finding. The results provide useful information for operating as a positive reinforcement of the tendency to use antioxidant and antimicrobial properties as a guideline of the rational design of this class of compounds. It needs further detailed investigations such as in vivo pharmacokinetic profile, toxicity, the mechanism(s), are needed to evaluate their potential of developing into the therapeutic agents.

\section{AUTHORS CONTRIBUTION}

Dr. N. D. Satyanarayan is the mentor involved in designing and is the supervisor of the overall work. Mr. Anantacharya R is mainly involved in synthesis/characterization of entitled molecules and carried out in silico pharmacokinetic studies and their interpretation. Dr. K M. Mahadevan involved in the idea generation of in the generation of new coupled heterocyclic analogues; Mr. Sameer P. was instrumental in carrying out in vitro antimicrobial and antioxidant results. Mr. Adarsha is helped in generating the spectral data.

\section{ACKNOWLEDGEMENT}

The authors are thankful to Kuvempu University, for providing necessary facilities to carry out the present work, one of the authors (Mr. Anantacharya) is thankful to the DST Government of India, for awarding Inspire fellowship (IF140251), and the authors are thankful to Dr. V. H. Kulkarni, Principal, Soniya Pharmacy College Dharwad, Karnataka, India for providing IR spectral data.

\section{CONFLICT OF INTERESTS}

There is no any conflict of interest

\section{REFERENCES}

1. Madhavi DL, Deshpande SS, SulunkheDK. Food antioxidants: technological, toxicological and health perspectives. Marcel Dekker Inc., NewYork, USA; 1996.

2. Collier A, Wilson R, Bradley H, Thomson JA, Small M. Free radical activity is type 2 diabetes. Diabetic Med 1990;7:27-30.

3. Baynes JW. Role of oxidative stress in the development of complication indiabetes. Diabetes 1991;40:405-12.

4. Halliwell B, John Gutteridge MC.Free radicals in biology and medicine. $2^{\text {nd }}$ ed.New York: Clavendon press; Oxford; 1989.

5. Kerr ME, Bender CM, Monti EJ.An introduction to oxygen free radicals. Heart Lung 1996;25:200-9.

6. Yanga J, Guoa J, Yuanb J.In vitro antioxidant properties of rutin. LWT-Food Sci Tech2008;41:1060-6.

7. Schneiders GE, Stevenson R.Synthesis of (+-)-machicendiol. J OrgChem1979;44:4710-1.

8. Carlsson B, Singh BN, Temciuc M, Nilsson S, Yi-Lin L, Mellin C, et al. Synthesis and preliminary characterization of a novelantiarrhythmic compound (KB130015) with an improved toxicity profile compared with amiodarone. J MedChem 2002;45:623-30.

9. Shirota O, Pathak V, Sekita S, Satake M, Nagashima Y, Hirayama Y,et al. Phenolic constituents from Dalbergia cochinchinensis. J Nat Prod 2003;66:1128-31.
10. Fuganti C, Serra S. A newapproachto 2-aryl-7-alkoxybenzofurans: Synthesis of ailanthoidol, a naturalneolignan. Tetrahedron Lett1998;39:5609-10.

11. Abdel-Wahab BF, Abdel-Aziz HA, Ahmed EM. Synthesis and antimicrobial evaluation of 1-(benzofuran-2-yl)-4-nitro-3arylbutan-1-ones and 3-(benzofuran-2-yl)-4,5-dihydro-5-aryl1-[4-(aryl)-1,3 thiazol-2-yl]-1H-pyrazoles. Eur J Med Chem2009;44:2632-5.

12. Basawaraja KM, Agasimundin YS. Synthesis and antimicrobialactivity of some 3-methoxybenzofuran-2-carbamates and carbamides. Indian J Heterocycl Chem2002;12:1-4.

13. Riddhi M, Karvekar MD, Sandip P, Sibaji S. Synthesis and biologicalevaluation of some benzofuran derivatives. Asian J Chem2009;21:5151-4.

14. Santana L, Teijeira M, Uriarte E, Teran C, Linares B, Villar R,et al.AM1 theoretical study, synthesis and biological evaluation of somebenzofuran analogues of anti-inflammatory aryl-alkanoic acids. Eur J Pharm Sci1998;7:161-6.

15. Van Wijngaarden I, Kruse CG, VanHesR, van der HJA,Tulp MT. 2-Phenylpyrroles as conformationally restricted benzamide analogues. A new class of potential antipsychotics. J Med Chem1987;30:2099-104.

16. Aruna Kumar DB, Prakash GK, Nandeshwarappa BP, Kiran BM, Sherigara BS, Mahadevan KM. Microwave-assisted synthesis and pharmacological evaluation of some potent naptho and benzofuro, thiazolyl, oxazolyl, thio and oxadiazalyl derivatives. Indian J Pharm Sci2006;68:809-14.

17. Witiak DT, Howard AI, Newman GK,Poochikian WL, Sankarappa SK. Comparative antilipidemic effects of various ethyl 5-substitutedbenzofuran-2, 3-dihydrobenzofuranand $3(2 \mathrm{H})$-benzofurannone-2-carboxylate analogs of clofibrate in atriton hyperlipidemic rat model. Lipids1976;11:384-91.

18. Dauzonne D, Gillardin JM, Lepage F,Pointet R, Risk S, Lamotte G, et al.Synthesis and some CNSactivities of new benzofuranylacryloylpiperazines. EurJ Med Chem1995;30:53-9.

19. Basawaraj R, Shashikanth G, Hugar MH,Sangapure SS. Synthesis and biologicalevaluation of benzofuro[3,2-d]pyrimidines. Indian J Heterocycl Chem2009;18:329-32.

20. Yu XY, Hill JM, Yu G, Yang YF, Kluge AF, Keith D,et al.A seriesofquinoline analogues as potent inhibitors of $\mathrm{C}$. Albicansprolyl tRNA synthetase. Bioorg Med ChemLett2001;11:541-4.

21. Melendez Gomez CM, Kouznetsov VV, Sortino MA, Alvarez SL, Zacchino SA. In vitro antifungal activity of polyfunctionalized 2(hetero) diarylquinolines prepared through iminodiels-alder reactions.Bioorg Med Chem2008;16:7908-20.

22. Chen YL, Zhao YL, Lu CM, Tzeng CC, Wang JP. Synthesis, cytotoxicity andanti-inflammatory evaluation of 2-(furan-2-yl)4-(phenoxy) quinolone derivatives part-4. Biol Med Chem2006;14:4373-8.

23. Yeh-Long C, I-Li C, Tai-Chi W, Chein-Hwa H, Cherng-Chyi T.Synthesis and anticancer evaluation of certain 4anilinofuro[2,3-b] quinolone and 4-anilinofuro[3,2-c] quinolone derivatives. Eur J Med Chem2005;40:928-34.

24. Chen IL, Chen YL, Tzeng CC.An efficient synthesis of antitumor 4-anilinofuro [2, 3-b] quinoline derivatives. Chin PharmJ2003;55:49-53.

25. Robert DL, Edward GC, Anthony OK, Paul D,Thomas RV,Paul JR. The practical route to anew class of $\mathrm{LTD}_{4}$ receptor antagonists. J Org Chem1996;61:3398-405.

26. Bilker O, Lindo V, Panico M, Etienne EA, Paxton T, Dell A,et al. Identification of xanthurenic acid asthe putativeinducer of malaria development in the mosquito. Nature 1998;392:289-92.

27. Roma G, Braccio MD, Grossi G, Mattioli F, Ghia M. 1,8NaphthyridinesIV. 9-substituted N,N-dialkyl-5-(alkylaminoor cycloalkylamino)[1,2,4] triazolo[4,3-a][1, 8]naphthyridine-6carboxamides,new compounds with anti-aggressiveand potent anti-inflammatory activities. Eur J Med Chem2000;35:1021-35.

28. Chen YL, Fang KC, Sheu JY, Hsu SL, Tzeng CC. Synthesis and anti bacterial evaluation of certain quinolone derivatives. J MedChem2001;44:2374-7.

29. Kalluraya B, Sreenivasa S. Synthesis and pharmacologicalproperties of some quinoline derivatives. IL Farmaco1998;53:399-404. 
30. Maguire MP, Sheets KR, McVetySpada AP, Zilberstein A.A new series of PDGF receptortyrosine kinase inhibitors: 3substitutedquinoline derivatives. JMed Chem1994;37:2129-37.

31. Huma HZS, Halder R, Kalra SS, Das J, Iqbal J. Cu (I)-catalyzed three componentcoupling protocol for the synthesis ofquinoline derivatives. Tetrahedron Lett2002;43:6485-8.

32. Viegas-Junior C, Danuello A, da Bolzani VS, Barreiro EJ, Fraga CA. Molecularhybridization: auseful tool in thedesign of new drugprototypes. CurrMed Chem2007;14:1829-52.

33. Anantacharya R, Manjulatha K, Satyanarayan ND, Santosh kumar S, Kaviraj MY. Antiproliferative, DNA cleavage, andADMET study of substituted 2-(1-benzofuran-2-yl) quinoline-4-carboxylic acid and its esters. Cogent Chem2016;2:1158-382.

34. Santoshkumar S, Manjulatha K, Satyanarayan ND, Anantacharya R, Harishkumar S, Harishkumar $\mathrm{HN}$, et al. Antiproliferative, ADME and potential in silico g6pdh inhibitory activity of novel 2-(1-benzofuran-2-yl)-4-(5-phenyl-4h 1, 2, 4triazol-3-yl) quinoline derivatives. Int $\mathrm{J}$ Pharm PharmSci2016;8:313-9.

35. Santhosha SM, Satyanarayan ND, Mahadevan KM, Yogesh DB, Menaka T. Synthesis, antiplasmodial and ADMET studies of 4methylamino-2-phenylquinolineanalogs. Int J Pharm Pharm Sci 2016;8:173-9.

36. Manjunatha KS, Manu CP, Satyanarayan ND, Vinay KN, Vineetha MS, Sunil More S.Acetylcholinesterase inhibitory effect of 3(1h-indol-3-yl)-1, 3-diphenylpropan-1-one derivatives. Asian J Pharm Clin Res 2017;10:83-6.

37. Shivananda MK, Shet Prakash M.Synthesis, characterization andantibacterial activity studies of sometriazolothiadiazolylquinolines. JChem Pharm Res 2011;3:61-6.
38. Feixiong C, Weihua L, Yadi Z, Jie S, Zengrui W, Guixia L. ADMETSAR: a comprehensive sourceand free tool for assessment of chemical ADMET properties.] ChemInformMod2012;52:3099-103.

39. Lin JH, Yamazaki M. Role of P-glycoprotein in pharmacokinetics: clinical implications. ClinPharma2003; 42:59-98.

40. Christopher AL, Franco L, Beryl WD, Paul JF. Experimental and computational approaches to estimate solubility and permeability in drug discovery and development settings. Adv Drug Delivery Rev 2001;46:3-26.

41. Blois MS. Antioxidant determination by the use of a stablefree radical. Nature 1958;26:1199-200.

42. Ruch RJ, Cheng SJ, Klaunig JE.Prevention of cytotoxicity andinhibition of intracellular communication by antioxidant catechins isolated from Chinesegreen tea. Carcinogenesis1989;10:1003-8.

43. Saundane AR, Rudresh K, Satyanarayan ND, Hiremath SP. Pharmacological screening of $6 \mathrm{H}, 11 \mathrm{H}$-indol $[3,2-\mathrm{c}]$ isoquinolin-5-ones and their derivatives. Indian JPharm Sci1998;60:379-83.

44. Manoj K, Agarwal RC, Sanjay D, Rai VK, Benito J. Antimicrobial activity of aqueous extract of terminaliachebula RETZ. On gram-positive and gram-negative microorganisms. Int J Cur Pharm Res 2009;1:56-60.

45. Junab A, Biswajit D, Trideep S. Antimicrobial activity of lemon peel (citrus limon) extract. Int J Curr Pharm Res 2017;9:7982.

46. Collins CH, Lynes P, Grange JM. Microbiological methods. 8th ed. Londan: Arnold; 1998. 